\title{
적정기술을 통한 한국의 원조효과성 제고를 위한 제언1)
}

하 재 웅 (하나를 위한음악재단 자원개발팀장)

\section{목 차}

1. 서론

2. 파리선언과 부산 글로벌 파트너십의 측정 지표

가. 개관

나. 한국의 파리선언 이행평가 결과

다. 부산 글로벌 모니터링 지표의 내용

3. 공적개발원조 질적평가(QuODA)의 측정 지표

가. 개관

나. 한국의 공적개발원조 질적평가

4. 적정기술 도입을 통한 한국 $\mathrm{ODA}$ 의 시사점

가. 적정기술 도입에 따른 한국 ODA 질적 평가 예상치

나. 적정기술 도입을 통해 개발효과성을 높이기 위한 정책적 과제

5. 결론

\section{1. 서 론}

1960년대 중반 제3세계의 경제적 · 기술적 - 사회적 문제들이 제기 되자 영국의 경제학자 $\mathrm{E}$. F. 슈마허(E. F. Schumacher)를 비롯한 몇몇 학자들은 전통사회의 기존 조건들과 기술적 발 전이 조화를 이루면서 경제적 개선을 도모할 수 있는 방법을 개발하려 노력했다. 2) 1973년, 슈 마허는 적정기술 분야의 기념비적 저서로 꼽히는 “작은 것이 아름답다(Small is beautiful)”라 
는 책에서 "중간기술(intermediate technology)" 이라 부르는 개념을 발전시켰고, 이는 오늘날 까지도 적정기술 운동의 기초를 제공하고 있다. 처음 슈마허가 중간기술 아이디어를 구상하였 을 때, 중간기술은 값싼 에너지의 전성기 시대에 서구의 대규모, 노동축소 기술보다는 빈곤국의 자원과 필요에 적합한 소규모이며 간단하며 저자본의 기술을 의미했다. 그러나 얼마 지나지 않 아 부국에서도 그 상황에 적합한 새로운 형태의 기술이 필요하다는 것이 증명되기 시작했다. 자 원(기름) 부족과 환경 파괴, 비인간적인 노동에 대한 저항, 실업과 같은 위기 상황 속에서 남·북 반구 모두에서 소규모이며 간단하고, 저자본, 비폭력적, 인간 중심이 되는 경제적인 기술의 필 요성이 대두되었다. ${ }^{3)}$

슈마허가 제시한 중간기술은 종종 적정기술, 대안기술로 표현되기도 하지만, 오늘날에는 적 정기술이 다른 두 개념에 비해 선호되는데 이는 세 개념이 모두 비슷한 의미를 지니고 있음에도 불구하고 중간기술이나 대안기술의 경우 이것이 항상 적절한 기술을 의미하는지 명확하지 않기 때문이다. ${ }^{4)}$

한국의 경우는 선진국들과 달리 적정기술의 역사가 길지 않다. 그동안 한국에서 적정기술은 큰 주목을 받지 못했고. ODA 분야에의 적용 역시 미비한 수준에 불과했다. 하지만 5 6년 전부 터 적정기술에 대한 관심이 높아지고 있으며 민간단체에서부터, $\mathrm{NGO}$, 사회적 기업까지 적정기 술을 활용하고자 하는 곳이 점차 증가하고 있다.5) 국내에서는 경제적인 에너지 효율측면에서 적정기술이 보급되기에 한계성이 있었다. 그래서 환경과 대안적 생태 공동체 등에서 새로운 대 안 활동으로서의 의미를 가지고 진행하는 경우가 많았다. 그러나 최근 개발도상국들에서 적정 기술과 관련된 다양한 프로젝트가 진행되고 그 사례들이 한국에서 소개되면서 국제개발협력분 야에서 적정기술을 활용하기 위한 다양한 시도들이 진행되고 있는 중이다.

이 글은 국제개발협력 분야에서 활성화되고 있는 적정기술이란 분야가 한국의 원조효과성에 미치게 될 영향에 대해서 살펴보고자 한다. 한국은 2009년 OECD DAC의 회원국이 됨으로써 국제적 표준에 부합하는 기준을 따를 수밖에 없게 되었다. 이 글은 원조와 관련된 평가들 중에 서 세계개발원조총회(High Level Forum, HLF)에서 논의되었던 파리선언의 평가 지표와 최 근 만들어진 부산 글로벌 모니터링 지표를 통해서 원조의 효과성을 점검하고 예측하였다. 또 원 조의 보다 질적인 부분을 점검하고 예측하기 위해서 세계개발센터(Center for Global

1) 이 글은 홍성욱 - 하재웅 외 5명이 작성한 「적정기술을 활용한 ODA의 효과적 추진방안에 대한 연구」(2010년)를 수정 · 편집해서 작성된 원고임을 밝힙니다.

2) Winner 'The Whale and the Reactor. 1st ed」, University of Chicago Press, 1986, p. 61 
Development)와 브루킹스 연구소 산하의 세계경제개발연구소(Global Economy and Development at Brookings)가 진행하는 '공적개발원조의 질적 평가(Quality of Official Development Assistance Assessment, QuODA)'를 기준으로 적정기술에 대한 원조효과성 을 모색해 보고자 한다.

\section{2. 파리선언과 부산 글로벌 파트너십의 측정 지표}

\section{가. 개관}

2000년 뉴욕에서 개최된 UN 새천년 정상회의(Millennium Summit)에서는 세계 189 개국 정상들의 합의를 통해서 원조에 대한 국제적 아젠다인 새천년개발목표(Millennium Development Goals, 이하 MDGs)가 발표되었다. 지구촌 빈곤퇴치를 위한 8개의 구체적인 개 발목표와 20 개의 세부목표 및 60 여 개의 지표로 이루어진 MDGs는 전세계 원조의 큰 기준을 제시했다는 점에서 의의를 가지고 있다. 그리고 나서 2002년에는 이 MDGs를 달성하기 위한 방안으로서 개발재원을 확보하기 위한 회의가 멕시코 몬테레이에서 개최되었고, 그 결과 매년 국민총생산(Gross National Income)의 0.7\%를 ODA 금액으로 사용하자는 합의를 만들어 냈 다. 그러나 국제사회에서는 이렇게 마련된 재원이 원조에 보다 효과적으로 사용될 수 있도록 노 력해야한다는 주장이 제기되었고 이에 $\mathrm{OECD} / \mathrm{DAC}$ 국가들은 이를 위한 고위급회담을 진행하 기에 이르렀다. 그렇게 해서 만들어진 것이 2003년 이탈리아 로마에서 개최된 1차 원조효과성 제고를 위한 고위급회담(High Level Forum)이었다. 회담에 대한 결과로 만들어진 것이 '원조 조화에 대한 로마선언' (이하 로마선언)이다. $\left.{ }^{6}\right)$

그러나 로마선언에서 발표된 원조의 조화가 공여자들 간의 협력적 조화에 그친다는 한계성을

3) George Mcrobie,' Small is Possible」 HarperCollins Publishers, 1981, p. 13-14

4) Bakker, $\ulcorner$ The Gandhian Approach to Swadeshi or Appropriate Technology: A Conceptualization in Terms of Basic Needs and Equity」, Journal of Agricultural and Environmental Ethics, 1990, p. 71

5) 국내에서 초기부터 지금까지 적정기술과 관련해서 활동해오고 있는 단체로 $\mathrm{NGO}$ 에서는 굿네이버스, 크리스천과학 기술 포럼, 나눔과기술, 국경없는과학기술연구회 등이 있고 학교로는 한동대 CRAIST90\%, 한밭대학교 적정기술 연구소 등이 사회적기업으로는 대안기술센터, 에너지팜 등이 있다.

6) 한재광 외 6, 「파리선언을 넘어서」ODA Watch 2012. p21 
극복하기 위해서 2005년 파리에서는 제 2차 고위급회담(HLF-2)을 열어 '원조효과성 제고를 위한 파리선언(이하 파리선언)' 을 만들어 냈다. 이 파리선언에서는 원조의 효과적인 집행을 위

해서 5 가지의 원칙과 12 가지의 지표를 제시하여 각 원칙의 이행을 측정할 수 있는 실질적인 지 표를 만들었다는 의의를 가지고 있었다. 파리선언의 이행을 점검하고 이를 보안하기 위해서 2008년 가나 아크라에서는 제 3차 원조효과성 제고를 위한 고위급 회담(HLF-3)이 진행되었고 이를 통해 국가차원의 발전전략을 넘어서 시민사회를 포함해서 다양한 원조행위자들을 포함했 다는 것이 이 회담의 가장 큰 의의였다.

2010년 '파리선언 이행 모니터링' 결과가 마무리되었고 세계는 그 미흡한 결과를 보안하기 위한 새로운 원조 논의의 개발을 위해 2011년 부산에서 세계개발원조총회(HLF-4)가 진행되었 다. 이번 대회에서는 170 여 국가의 총리 및 장관급 대표단, 78 개 국제기구와 세계시민사회 대 표, 학계와 민간기업 등에서 2500여명이 참여하여 관련 의제를 정리하고 전략을 수립했다. $\left.{ }^{7}\right)$

부산총회 결과문서의 핵심 내용으로는 국제사회가 개발을 위한 공동의 목적을 성취하기 위 해 추구해야할 원칙으로 ‘주인의식, 성과중심, 포괄적 개발 파트너십, 투명성 및 상호책무성' 을 명시하고 있다. 부산총회의 최대 성과로 인정되는 것은 원조의 효과성을 넘어서 개발협력의 지 평(landscape)을 넓히는 개발효과성에 대한 논의로 확대되었다는 점이다. 기존의 총회에서는 원조의 효과성을 위해서 $\mathrm{OECD/DAC}$ 회원국 중심의 공여국들과 파트너국가들에 대한 역할과 책임성을 주로 논의했다면 이번 대회에서는 신흥 공여국, 의회, 지방정부를 넘어 민간 기업, 민 간 재단 및 시민사회 등 많은 행위자들이 공식적인 개발의 주체로 포함되었다는 것이 가장 큰 의의로 평가되고 있다. 또한 이번 총회에서 처음으로 등장한 빌딩블록(Building Block)의 개념 은 국제사회가 합의한 사항을 구체적으로 이행하기 위한 실행방안을 담은 문서로, 이번 대회에 서 참여한 각국 정부, 국제기구, 시민사회단체들이 개발협력 관련 주요 의제에 대한 빌딩블록 제안서를 약 40 개 정도 제출하였는데, 이 문건을 통해서 그 동안 표면화되기 어려웠던 인권, 성 평등, 민주적 주인의식 등의 진보적인 표현들도 등장했다. ${ }^{8)}$

원조효과성과 관련된 여러가지 논의 가운데 파리선언이 의미를 가지고 있는 것은 명확한 측 정 지표를 통해서 원조의 효과성을 평가했다는 점이다. 따라서 이 장에서는 파리선언 5 대 과제 측정지표를 통해서 한국의 원조효과성을 점검해보고, 향후 전개될 부산 글로벌 파트너십에 대 한 지표 내용을 통해서 원조효과성 제고를 위한 향후 과제를 점검해 보고자 한다.

7) 참조 http:://www.kofid.org 및 http://www.redi.re.kr

8) 국제개발협력시민사회포럼(KoFID)「이슈 브리프 8호」글로벌발전연구원(ReD), 2011 


\section{나. 한국의 파리선언 이행평가 결과}

$\mathrm{OECD}$ 는 많은 기대 속에 지난 2010년 파리선언의 원칙 이행에 대한 마지막 '파리선언 이행 모니터링(Survey on Monitoring the Paris Declaration)'을 실시했다. 파리선언 이행에 대 한 이러한 점검은 지난 2005년 파리선언이 제정된 이래 2005년과 2007년, 그리고 2010년 3차 례 실시되었다. 2010년 파리선언 이행 모니터링은 파리선언의 마지막 평가이면서 이 결과가 향 후 원조효과성 논의 방향에 미치는 영향도 매우 크기 때문에 결과에 대한 기대가 매우 높았다. ${ }^{9)}$ 그러나 수행하기로 약속했던 12 개의 지표 중에서 달성에 성공한 지표는 4 번째 지표인' 조화로 운 지원을 통한 역량강화 '한 항목뿐이다. 따라서 이러한 항목들은 향후 전개되는 부산 글로벌 파트너십에 있어서도 유사하게 이어질 수밖에 없으며 파리선언 사례를 통해서 보다 실질적으로 이행을 강제화하거나 실행을 높일 수 있는 방안에 대한 부분이 주요한 이슈로 부각될 것으로 보 인다.

우리나라도 파리선언의 가입국으로서 파리선언에서 채택한 5 가지 목표 달성을 위하여 노력 해 왔다. 이에 대한 일환으로 한국은 2006년 파리선언 모니터링 설문에서 3개국10)에 대한 설문 에 참여하였고, 2008년에서는 13개국11)으로 대상 국가를 늘려서 참여하였다.12) 두 번의 모니 터링은 해당국가의 유, 무상 원조 기관에서 실시한 내용의 자료를 공관에서 취합하였다. $\mathrm{KOICA}$ 의 경우, 2008년 모니터링 참여를 위해 대상국 공관과 사무소에 설문조사에 대한 지침 과 파리선언에 대한 인식제고를 위한 설명회를 개최하는 등의 노력을 기울였으나, 여전히 파리 선언 등 국제적 개발 동향에 대한 인식과 이해 부족으로 인해 타 공여국과 같은 체계적인 모니 터링이 이루어지지 못했다. ${ }^{13)}$

2006년에 실시된 1차 파리선언 이행평가 조사 결과를 보면, 제한된 조사 대상에도 불구하고 원조일치와 조화에 대한 한국의 성과와 도전과제를 보여주었다. 지표 4인 협력대상국 프로그램 에 일치하는 기술협력(74\%)과 협력대상국 공공조달시스템 활용(45\%)을 제외하고는 거의 모든 항목에서 $\mathrm{DAC}$ 국가들의 평균에 많이 못 미치는 수준이었다. 2008년에는 각 지표에서 다소 개 선되기는 하였으나, 공동조사 실시에서 $15 \%$ 를 보인 것 외에는 큰 진전은 없었다. 그러다가

\footnotetext{
9) 한재광 외 6, 「파리선언을 넘어서」ODA Watch 2012. p25

10) 알바니아, 몽골, 베트남

11) 아프가니스탄, 방글라데시, 캄보디아, 이집트, 에티오피아, 인도네시아, 라오스, 몽골, 네팔, 페루, 필리핀, 탄자니아, 베트남

12) OECD-DAC, 「Special Review of Korea」, p.22

13) 박수영, 조아영, 2009. 「원조효과성을 위한 파리선언 이행체제평가연구 보고서」p. 95
} 
2010년에는 기존에는 높은 달성률을 보인 지표 4의 기술협력부분은 $11 \%$ 로 대폭 감소된 반면, 지표 3의 협력대상국 예산에 통합된 원조는 $46 \%$ 로 향상되었고 기타 지표 10(b)의 공동 국별 연 구 실시는 $50 \%$ 를 보여주며 전체 공여국 수준을 넘었다. 뿐만 아니라 지표 8 비구속성 원조 (42\%)와 지표9 PBA의 비율(42\%)에 있어서는 괄목할만한 성과를 보여주고 있으나 목표치를 달 성하지는 못한 것으로 나타났다. ${ }^{14)}$

〈표 1〉 한국의 파리선언 이행 평가내용15)

\begin{tabular}{|c|c|c|c|c|c|c|c|}
\hline \multirow{2}{*}{\multicolumn{2}{|c|}{ 지표 }} & \multicolumn{2}{|c|}{2006} & \multicolumn{2}{|c|}{2008} & \multicolumn{2}{|c|}{2010} \\
\hline & & \multirow{2}{*}{$\begin{array}{r}\text { 한국 } \\
12 \%\end{array}$} & \multirow{2}{*}{$\begin{array}{l}\text { DAC } \\
\text { 평균 } \\
88 \%\end{array}$} & \multirow{2}{*}{$\begin{array}{l}\text { 한국 } \\
34 \%\end{array}$} & \multirow{2}{*}{$\begin{array}{c}\text { 06,08년 } \\
\text { 참가자 } \\
\text { 평균 }\end{array}$} & \multirow{2}{*}{$\begin{array}{l}\text { 한국 } \\
46 \%\end{array}$} & \multirow{2}{*}{$\begin{array}{r}\begin{array}{c}\text { 전체 } \\
\text { 공여국 }\end{array} \\
41 \%\end{array}$} \\
\hline 3 & $\begin{array}{l}\text { 협력대상국 예산에 } \\
\text { 통합된 원조 }\end{array}$ & & & & & & \\
\hline 4 & $\begin{array}{c}\text { 협력대상국 프로그램에 } \\
\text { 일치하는 기술협력 }\end{array}$ & $74 \%$ & $48 \%$ & $79 \%$ & $60 \%$ & $11 \%$ & $57 \%$ \\
\hline 5(a) & $\begin{array}{c}\text { 협력대상국 공공재정 } \\
\text { 관리(PFM)시스템 활용 }\end{array}$ & $45 \%$ & $40 \%$ & $10 \%$ & $45 \%$ & $0 \%$ & $48 \%$ \\
\hline $5(b)$ & $\begin{array}{c}\text { 협력대상국 공공조달 } \\
\text { 시스템 활용 }\end{array}$ & $0 \%$ & $39 \%$ & $5 \%$ & $43 \%$ & $37 \%$ & $44 \%$ \\
\hline 6 & 평행 PIU의 숫자 & 0 & - & 11 & 16013) & $4 \%$ & 158 \\
\hline 7 & 예측 가능한 원조 & $12 \%$ & $70 \%$ & $19 \%$ & $46 \%$ & $32 \%$ & $43 \%$ \\
\hline 8 & 비구속성 원조 & - & $75 \%$ & - & $88 \%$ & $42 \%$ & $86 \%$ \\
\hline 9 & PBA의 비율 & $0 \%$ & $43 \%$ & $1 \%$ & $7 \%$ & $42 \%$ & $45 \%$ \\
\hline $10(a)$ & 공동 조사 실시 & $0 \%$ & $18 \%$ & $15 \%$ & - & $8 \%$ & $19 \%$ \\
\hline $10(b)$ & 공동 국별 연구 실시 & - & $42 \%$ & $0 \%$ & - & $50 \%$ & $43 \%$ \\
\hline
\end{tabular}

14) 김형규, 「파리선언 이행평가 최종보고서 발표」주OECD대표부(http://oecd.mofat.go.kr) 2011

15) 저자 재구성 / 출처 :OECD-DAC, 2008. rSpecial Review of Korea」, p.22, Table.4; OECD-DAC, 2008, 「2008 Survey on Monitoring the Paris Declaration」, p.92-100, 123 


\section{다. 부산 글로벌 모니터링 지표의 내용}

부산총회 합의사항 이행으로 지난 6월 28일과 29일에는 프랑스 파리에서 글로벌 모니터링 체 제에 대한 상세 내용에 합의했다. 부산총회의 주요 공약 및 합의사항 이행 점검을 위해서 글로 벌 파트너십이 공식 출범한 것이다. 2010년을 기준 연도로 2015년을 목표로 글로벌 차원에서 모니터링이 필요한 분야를 전략적으로 선별해서 진행하기로 합의한 것이다. 이번에 합의한 10 개의 지표 중 협력대상국 시스템 활용, 비구속화, 원조 예측성(중/단기), 투명성 등의 항목은 기 존 파리선언의 내용을 심화 발전시킨 것이다. 반면에 부산총회를 통해서 개발효과성이라는 개 념을 명시적으로 결과문서에 포함시킬 수는 없었지만, 이번 지표에 추가된 개도국 결과 프레임 워크 활용, 시민사회 참여, 민간분야 역할, 양성평등 등은 개발효과성과 관련된 신규 지표라고 할 수 있다. 이 지표들 중 일부 지표(시민사회, 민간, 양성평등)의 경우 세부 지표의 정의 및 평 가 방법 등은 금년 12 월 말까지 확정지을 예정이다. 모니터링 지표에서 제외된 공약들은 개도국 국별 모니터링 및 장관급 회의에서 이행여부를 점검할 수 있다. 부산 글로벌 모니터링은 자발적 인 참여를 원칙으로 하며, 특히 남남협력국에 대해서는 글로벌 파트너십 참여와 글로벌 모니터 링 참여를 분리함으로써 글로벌 모니터링에 참여하지 않더라도 글로벌 파트너십의 정책대화에 참여할 수 있는 정책적 융통성을 부여했다. 16$)$

\section{〈표 2〉 부산 글로벌 모니터링 지표(안)}

\begin{tabular}{l|l|l|l}
\hline \multicolumn{1}{|c|}{ 부산 글로벌 지표 } & \multicolumn{1}{|c|}{ 지표 설명 } & 목표치(2015년) & $\begin{array}{c}\text { 부산 } \\
\text { 결과문서 } \\
\text { 관련 조항 }\end{array}$ \\
\hline $\begin{array}{l}\text { 1. 협력대상국 우선순위 } \\
\text { 반영 }\end{array}$ & $\begin{array}{l}\text { 협력대상국의 우선순위 } \\
\text { 를 반영한 결과 프레임 } \\
\text { 워크 활용 정도 }\end{array}$ & $\begin{array}{l}\text { 모든 공여주체가 협력대 } \\
\text { 상국 결과 프레임워크 } \\
\text { 활용 }\end{array}$ & 18(a) \\
\hline 2. 시민사회 참여와 기여 & $\begin{array}{l}\text { CIVICUS 시민사회 환경 } \\
\text { 지수(Enabling } \\
\text { environment index)활용 }\end{array}$ & 지속적 향상 & 22(a) \\
\hline 3. 민간분야의 역량강화 & 추후 확정 & 지속적 향상 & 32(a) \\
\hline 4. 개발협력 정보 공개 & 공통의 공개 표준 활용 정도 & 모든 공여주체가 활용 & 23(c) \\
\hline 5. 예측가능성 & 개발협력의 예측 가능성 제고 & & 24(a) \\
\hline
\end{tabular}

16) 홍상희 「부산 글로벌 파트너십 출범과 우리나라 ODA 정책과제」KOICA 국제개발협력 2012년 3호 p14 


\begin{tabular}{|c|c|c|c|}
\hline 부산 글로벌 지표 & 지표 설명 & 목표치(2015년) & $\begin{array}{c}\text { 부산 } \\
\text { 결과문서 } \\
\text { 관련 조항 }\end{array}$ \\
\hline (a)단기 예측성 & $\begin{array}{l}\text { 해당 년도 계획된 원조 } \\
\text { 의 집행 비율 }\end{array}$ & $\begin{array}{l}\text { 집행되지 않은 비율 } \\
50 \% \text { 감소 }\end{array}$ & \multirow{2}{*}{ 24(a) } \\
\hline (b)중기 예측성 & $\begin{array}{l}\text { 중기 집행계획에 포함된 } \\
\text { 원조 비율 }\end{array}$ & $\begin{array}{l}\text { 포함되지 않은 비율 } \\
50 \% \text { 감소 }\end{array}$ & \\
\hline 6. 원조의 예산화 & $\begin{array}{l}\text { 개도국 의회 승인을 받은 } \\
\text { 연간 예산에서 원조 비율 } \\
\text { (2010년 기준) }\end{array}$ & $\begin{array}{l}\text { 정부에 지원되는 개발원조 } \\
\text { 중 정부 예산에 보고되지 } \\
\text { 않은 비율 } 50 \% \text { 감소 }\end{array}$ & 21(a) \\
\hline 7. 상호 책임성 & $\begin{array}{l}\text { 부산총회 합의사항 이행을 } \\
\text { 위한 포괄적인 상호평가 } \\
\text { 검토 참여 }\end{array}$ & 모든 개도국에서 도입 & $35(a)$ \\
\hline $\begin{array}{l}\text { 8. 양성평등과 여성 역량 } \\
\text { 강화 }\end{array}$ & $\begin{array}{l}\text { ㅇㅑㅑ성평등과 여성의 역량강 } \\
\text { 화를 위한 공공예산 배정 } \\
\text { 과 이를 추적하는 시스템 } \\
\text { 을 가진 국가의 비율(\%) }\end{array}$ & 모든 개도국에서 도입 & 20(a) \\
\hline 9. 협력대상국 시스템 활용 & \multirow{3}{*}{$\begin{array}{l}\text { 효과적인 제도 구축을 위 } \\
\text { 한 개도국 시스템 강화 및 } \\
\text { 활용(2010년 기준) }\end{array}$} & & \multirow{3}{*}{ 19(a) } \\
\hline $\begin{array}{l}\text { (a)개도국 공공재정관리 시 } \\
\text { 스템(PMF)의 질적 수준 }\end{array}$ & & $\begin{array}{l}\text { 개도국 } 50 \% \text { 이상에서 } \\
\text { PFM/CPIA 점수 최소 1단 } \\
\text { 계 상승 }\end{array}$ & \\
\hline $\begin{array}{l}\text { (b)협력대상국 PMF 및 조 } \\
\text { 달 시스템 활용 }\end{array}$ & & $\begin{array}{l}\text { 시스템을 사용하지 않는 } \\
\text { 비율 감축 }\end{array}$ & \\
\hline 10. 비구속화 & $\begin{array}{l}\text { 비구속성 원조 비율(\%) } \\
\text { (2010년 기준) }\end{array}$ & 지속적 향상 & $18(e)$ \\
\hline
\end{tabular}

\section{3. 공적개발원조 질적평가(QuODA)의 측정 지표}

\section{가. 개관}

앞의 파리선언과 부산 글로벌 모니터링과 같이 $\mathrm{OECD}$ 를 중심으로 하는 평가 방식 외에 원조 의 효과성과 관련해서 참고할만한 원조의 평가 지표로는 미국의 민간 싱크탱크인 세계개발센터 (Center for Global Development, CGD)에서 수행하는 공적개발원조 질적평가 
(Commitment to Development Index, CDI)와 브루킹스 연구소17) 산하의 세계경제개발연 구원(Global Economy and Development at Brookings)과 세계개발센터가 진행하는 '공적 개발원조의 질적 평가(Quality of Official Development Assistance Assessment)' 가 있다.

개발공헌지수(CDI)는 국별 개발에 대한 공헌도를 측정하기 위한 것으로 개발과 관련 있다고 여겨지는 7 개의 분야(원조, 무역, 투자, 이주, 환경, 안보, 기술)에서 선진국의 대내외정책이 가 난한 국가들의 발전을 얼마나 촉진했는지를 평가하여 수치화한 것이다. 개발공헌지수를 분야별 로 살펴보면 원조는 개발 재원을 제공하고, 무역은 개발도상국의 기업들이 더 넓은 시장으로 판 매 영역을 확대하면서 자국 내 고용을 창출하게 도와주며, 투자는 개발도상국에 산업 성장을 위 한 자본을 공급하여준다. 이주는 개발도상국의 노동자들이 더 높은 임금을 받을 수 있는 선진국 의 노동시장에 고용되어 자신들의 수익을 본국에 송금할 수 있게 해준다. 환경은 선진국의 환경 파괴가 개발도상국의 발전을 저해할 수 있다는 현실을 인식시켜주고, 안보는 개발의 선행 조건, 기술은 개발의 중요한 요소이기 때문이다. ${ }^{18)}$

반면 공적개발원조 질적평가(QuODA)는 국제사회에서 논의되는 양질의 원조가 되기 위한 4 가지 항목(효율성 극대화, 협력대상국 제도 발전, 협력대상국 행정부담 감소, 원조 투명성) 아래 총 31 가지의 세부 평가항목을 정하여 평가하고, 항목별로 각 국가와 원조기관의 평가를 비교할 수 있도록 했다. 공적개발원조 질적평가 평가팀은 2010년 첫 평가를 실시하였고, 2011년에는 두 번째 평가를 실시하였다. 1차 평가는 4개 분야(Dimension) 30개 지표를 중심으로 2008년 도에 보고된 데이터를 중심으로 평가되었고, 2차 평가에서는 31개 지표로 수정 보안하면서 2009년도에 수집된 데이터를 사용하였다.

17) 브루킹스 연구소(The Brookings Institution)는 공공 정책을 연구하는 비영리연구소로써, 헤리티니 재단과 함께 미국의 양대 전문연구소로서 민주당의 정책 브레인 역할을 해온 것으로 알려져 있다. 이들은 독립적으로 양질의 연구를 하고 그 연구를 바탕으로 미국 민주주의의 발전, 경제사회적 복지와 안전, 그리고 보다나은 국제 사회를 위하여 혁신적이고 실용적인 제안을 제공하는데 그 목적을 가지고 있다. 가장 영향력 있고, 가장 많이 인용되고 신뢰받는 씽크탱크로서의 자부심을 가지고 있음. 2005년 The Quarterly Journal of Economics에 실린 'A Measure of Media Bias' 연구 결과에 따르면, 헤리티지 재단은 공화당 의원들이 주로 인용한 반면, 미국 내의 많은 씽크탱크와 정책 그룹 중에서 브루킹스 연구소는 공화당, 민주당, 그리고 무소속에서 골고루 신뢰받고 인용 되는 연구소로 평가받고 있음. (네이버 용어사전, 검색일: 2012년 10월 3일; 브루킹스연구소 홈페이 지,http://www.brookings.edu/about/reputation.aspx, 검색일: 2012년 10월 3일)

18) 박수영, 고요한 「공적개발원조 질적평가(CDI)와 공적개발원조 질적평가(QuODA)를 통해 본 우리 원조 개선방안」 KOICA 개발정책 포커스 제 11호. 2012. p42 
〈표 3〉 공적개발원조질적평가(QuODA) 4대 평가분야 31개 세부지표19)

\begin{tabular}{|c|c|}
\hline 평가항목 & 세부항목 \\
\hline \multirow{8}{*}{$\begin{array}{c}\text { 효율성 최대화 } \\
\text { (Maximizing Efficiency) }\end{array}$} & 빈곤국에 대한 원조 할당 \\
\hline & 거버넌스를 잘하는 국가에 대한 원조 할당 \\
\hline & 낮은 행정 비용 \\
\hline & 높은 CPA비율 \\
\hline & 비교 우위가 있는 국가에 지원 \\
\hline & 비교 우위가 있는 분야에 지원 \\
\hline & 국제 공익 시설에 대한 지원 \\
\hline & 비구속성원조 비율 \\
\hline \multirow{8}{*}{$\begin{array}{c}\text { 협력대상국 제도 발전 } \\
\text { (Fostering Institutions) }\end{array}$} & 협력대상국의 개발 우선순위에 대한 원조 \\
\hline & 원조실시기구 이용의 방지 \\
\hline & 협력대상국 예산에 활용된 원조 \\
\hline & 좋은 운영전략을 이용한 원조 \\
\hline & 협력대상국의 시스템 사용 \\
\hline & 기술협력의 조화 \\
\hline & 계획된 원조가 실제 공여된 정도 \\
\hline & 미래의 예산 계획의 보급 \\
\hline \multirow{7}{*}{$\begin{array}{l}\text { 협력대상국 행정부담 감소 } \\
\text { (Reducing the } \\
\text { Administrative Burden) }\end{array}$} & 원조 관계의 중요도 \\
\hline & 원조기구의 분산화 \\
\hline & 중간 프로젝트 규모 \\
\hline & 다자기구 지원 \\
\hline & 공동 미션 \\
\hline & 공동 연구 실시 \\
\hline & 프로그램형 원조의 활용 \\
\hline \multirow{8}{*}{$\begin{array}{c}\text { 원조 투명성 } \\
\text { (Transparency and } \\
\text { learning) }\end{array}$} & IATI (International Aid Transparency Initiative) 가입 \\
\hline & 프로젝트 제목과 내용 기록제출 \\
\hline & 프로젝트의 세부내용 제공 \\
\hline & 원조 제공 방식에 대한 정보제공 \\
\hline & 원조 지급액에 대한 정보 제공 \\
\hline & 프로젝트 정보 제공 \\
\hline & 주요공여기관 평가정책의 질 \\
\hline & 좋은 모니터링, 평가 체제 \\
\hline
\end{tabular}




\section{나. 한국의 공적개발원조 질적평가}

한국의 공적개발원조 질적평가를 살펴보면 아래 [표 4]에 나타나는 바와 같이 첫 번째 평가에 서는 협력대상국 제도개선을 제외한 모든 항목이 꼴찌였으나 2011년에 발표된 자료에서는 효율 성 증대와 투명성과 학습 부분에서는 10 위 이상이나 상승하는 높은 개선결과를 보여주고 있다.

아일랜드의 경우 매년 모든 4 개 항목 모두 상위 10 위에 들었고, 덴마크와 일본 역시 2 개 항목 이 상위 10 위 안에 들면서 전체적으로 상위권에 속하는 평가를 받고 있다. 2011년 평가에서는 미국, 그리스, 오스트리아 등이 저조한 성적을 보였다. 〈그림 1)은 한국과 아일랜드 원조의 질적 평가를 비교하였다. 여기서 ' $O$ ' 은 평균값을 나타내며 (-)는 평균이하, 그리고 (+)는 평균이상을 나타낸다. 그림에서 보듯이 한국의 질적 성장이 이루어지고 있긴 하나 아직 다른 선진 공여국들 에 비해서는 대부분 평균 이하에 머무르고 있어 질적인 성장을 보다 적극적으로 모색해야하는 상태임을 알 수 있다.

〈표 4〉2011년 주요 국가 평가 결과20)

\begin{tabular}{c|c|c|c|c}
\hline & $\begin{array}{c}\text { 효율성 최대화 } \\
\text { (Maximizing } \\
\text { Efficiency) }\end{array}$ & $\begin{array}{c}\text { 협력대상국 제도발전 } \\
\text { (Fostering } \\
\text { Institutions) }\end{array}$ & $\begin{array}{c}\text { 협력대상국 } \\
\text { 행정부담 축소 } \\
\text { (Reducing Burden) }\end{array}$ & $\begin{array}{c}\text { 원조 투명성 } \\
\text { (Transparency } \\
\text { and Learning) }\end{array}$ \\
\hline 아일랜드 & 8 위 & 2위 & 2위 & 7위 \\
\hline 덴마크 & 15위 & 1위 & 5위 & 20위 \\
\hline 일본 & 7위 & 7위 & 23위 & 13위 \\
\hline 미국 & 29위 & 26위 & 31위 & 12위 \\
\hline 한국(2010) & 20위(30위) & 15위(16위) & 30위(31위) & 18위(30위) \\
\hline
\end{tabular}

19) 박수영, 고요한 「공적개발원조 질적평가(CDI)와 공적개발원조 질적평가(QUODA)를 통해 본 우리 원조 개선방안」 KOICA 개발정책 포커스 제 11호. 2012. p17

20) Nancy Birdsall외, "Quality of Official Development Assistance Assessment」,2010, p.42 Table.4 발췌 
그림 1. 한국 - 아일랜드 원조의 질적 평가 비교

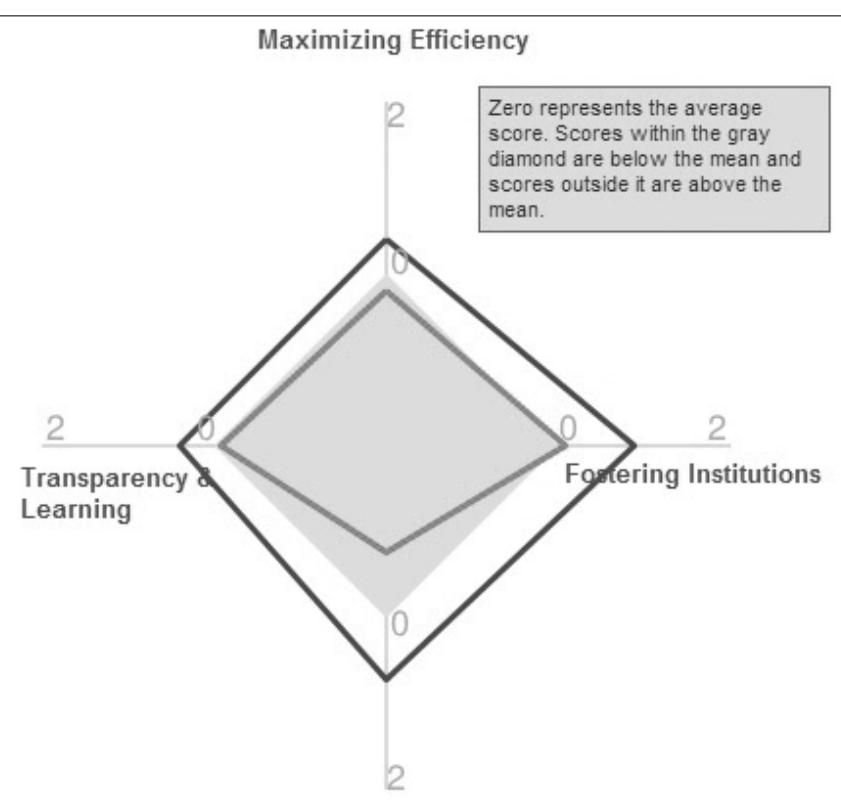

Reducing Burden

출처 : 세계개발(Center for Global Development 홈페이지21) (안쪽 : 한국, 바깥쪽 : 아일랜드)

\section{4. 적정기술 도입을 통한 한국 ODA의 시사점}

\section{가. 적정기술 도입에 따른 한국 ODA 질적 평가 예상치}

적정기술이 원조방식에 반영되는 방식은 수없이 다양하다고 할 수 있다. 독일의 GIZ(국제협 력공사; Gesellschaft fur Internationale Zusammenarbeit)처럼 원조기관자체를 적정기술 을 중심으로 설계할 수도 있으며, 네덜란드의 SNV(Netherland Development Organization, 네덜란드어로는 Stichting Nederlandse Vrijwilligers, 이하 SNV)처럼 $\mathrm{NGO}$ 형태의 운영 기구를 만들어서 운영할 수도 있고, 아니면, 프랑스의 국제개발농업연구소(이 하 CIRAD; Centre de Coopération Internationale en Recherche Agro nomique pour

21) http://www.cgdev.org/section/topics/aid_effectiveness/quoda 검색일 2012년 10월 28일. 
le Développement, French Agricultural Research Centre for International Development)형태로 정부출연의 연구소 형태로 적용할 수도 있다.

이처럼 다양한 방식 가운데 적정기술을 어떤 형태로 적용하는가에 따라서 원조효과성에 미치 는 영향은 참으로 다양하다고 할 수 있다. 따라서 아직 어떻게 적용할지에 대한 계획이 없는 상 태에서 적용에 대한 효과성을 예측하는 것에 큰 오류를 범하기 쉽다. 그러나 이 글에서는 적정 기술 자체가 가지고 있는 속성과 본질에 대한 접근을 통해서 효과성을 예측해보고자 한다.

1) 부산 글로벌 모니터링 지표에 따른 예상 효과

\section{〈표 5〉부산 글로벌 모니터링 지표에 따른 효과 예상}

\begin{tabular}{l|c|c|c}
\hline \multirow{2}{*}{ 부산 글로벌 지표 } & \multicolumn{3}{|c}{ 적정기술 도입에 따른 효과 } \\
\cline { 2 - 4 } & 높다 & 보통 & 약함 \\
\hline 1. 협력대상국 우선순위 반영 & & 0 & \\
\hline 2. 시민사회 참여와 기여 & 0 & & \\
\hline 3. 민간분야의 역량강화 & 0 & & \\
\hline 4. 개발협력 정보 공개 & 0 & & \\
\hline 5. 예측가능성(단기/중기) & & 0 & \\
\hline 6. 원조의 예산화 & & 0 & \\
\hline 7. 상호 책임성 & 0 & & \\
\hline 8. 양성평등과 여성 역량 강화 & & & \\
\hline 9. 협력대상국 시스템 활용 & & 0 & \\
\hline 10. 비구속화 & & 0 & \\
\hline
\end{tabular}

※ 출처 : 저자 재구성 / 참고문헌 : KOICA 국제개발협력 2012년 3호

지금까지 결정된 부산 글로벌 모니터링 지표를 보았을 때 파트너 국가의 상황에 맞춰서 적용 되는 적정기술이 도입된다면 거의 대부분의 지표에 있어서 긍정적 효과가 나타날 것으로 예상 된다. 이는 적정기술을 적극적으로 도입하기 위해서는 기존 프로젝트 중심의 원조 관행을 탈피 하고 프로그램 기반 접근(Program-Based Approach)으로 가야하는 속성을 가지고 있기 때문 이다. 또한 적정기술은 지속적으로 현지화된 전략을 추진하면서 다양한 파트너십 구축을 요구 하기 있기 때문에 부산 글로벌 모니텅 지표가 만들어지는 취지와 그 맥락을 함께 한다는 측면에 서 높은 긍정적 효과를 기대하는 것이다. 
가장 큰 효과가 나타날 것으로 보이는 지표는 바로 새로 도입된 2,3 지표와 4,7 번 지표이다. 적정기술은 현지화를 추구하기 때문에 인력과 기술적 전문성에 있어서 다양한 파트너십을 추구 할 수밖에 없다. 따라서 적정기술이 도입되면 원조 수행기관에서는 사업을 개발하고 평가하는 일에 주력하면서 다양한 정책적 결정에 집중하게 된다. 그러면서 시민사회와 민간분야의 다양 한 파트너십 개발에 높은 효과를 보게 될 것이다. 또한 개발협력 정보 공개측면에 있어서는 현 지화를 추구하는 적정기술의 속성상 현지에 대한 다양한 정보를 축적할 수밖에 없다. 또한 시민 사회 및 민간분야의 다양한 파트너십을 구축해야하기 때문에 그들로부터 들어오는 현지 정보들 에 대한 요구들 또한 높은 긍정적 효과를 가져오게 된다. 또한 상호책임성 부분에 있어서도 파 트너십의 다양성 그리고 끝임 없는 현지화 전략을 요구하는 적정기술의 특성을 생각한다면 높 은 성과를 기대할 수 있다.

다음으로 중간정도의 효과를 보일 것으로 예상되는 항목은 $1,5,6,9,10$ 번 지표이다. 협력 대상국의 우선순위를 반영해서 결과 프레임워크를 활용하는 측면과 파트너 국가의 승인을 받는 원조의 예산화라고 하는 측면은 적정기술이 가진 현지화 전략이라는 측면에서 중간정도의 긍정 적 효과를 기대할 수 있다. 그리고 단기와 중기의 예측 가능성이라는 측면은 적정기술을 도입하 기 위해서 전제가 되어야하는 프로그램 기법의 도입이라는 측면에서 어느 정도 효과가 있을 것 이라고 예측하였다. 또 파트너 국가 시스템 활용이라는 측면을 생각하면 지역 주민들의 역량에 초점을 두고 보다 장기적인 프로그램 중심의 사업을 지향한다는 측면에서 긍정적 효과를 미칠 것으로 예상된다. 비구속화 부분에 있어서는 한국이 급격한 향상을 보이고 있는 부분이다. 아직 한국에서는 적정기술에 대한 국제적 경쟁력을 갖추지 못하고 있는 실정이다. 따라서 적정기술 도입 초기 부분에 있어서는 한국의 이해관계에 있어서 불리한 측면이 있기 때문에 오히려 약화 될 수 있는 여지도 가지고 있다. 그러나 적정기술은 기술에 대한 중요도보다 현지화에 대한 중 요도가 강하므로 지역적 상황에 집중하게 되므로 보다 신속한 글로벌 경쟁력을 확보할 수 있다 는 측면이 작용한다.

마지막으로 긍정적 영향을 주기는 하겠지만, 적정기술과 직접적인 개연성이 약할 것으로 보이 는 지표는 8번이다. 새롭게 추가된 양성평등과 여성 역량강화라는 측면은 적정기술보다는 원조 정책에 있어서 우선순위를 두는 측면이 강하기 때문에 적정기술과 직접적인 개연성은 낮다고 본 것이다.

\section{2) 공적개발원조 질적평가(QuODA) 지표에 따른 예상 효과}


〈표 6〉 공적개발원조 질적평가 지표에 따른 예상 효과

\begin{tabular}{|c|c|c|c|c|}
\hline \multirow{2}{*}{ 평가항목 } & \multirow{2}{*}{ 세부항목 } & \multicolumn{3}{|c|}{ 적정기술 도입에 따른 효과 } \\
\hline & & 높다 & 보통 & 약함 \\
\hline \multirow{8}{*}{$\begin{array}{l}\text { 효율성 최대화 } \\
\text { (Maximizing } \\
\text { Efficiency) }\end{array}$} & 빈곤국에 대한 원조 할당 & & O & \\
\hline & 거버넌스를 잘하는 국가에 대한 원조 할당 & O & & \\
\hline & 낮은 행정 비용 & & O & \\
\hline & 높은 $\mathrm{CPA}$ 비율 & O & & \\
\hline & 비교 우위가 있는 국가에 지원 & O & & \\
\hline & 비교 우위가 있는 분야에 지원 & O & & \\
\hline & 국제 공익 시설에 대한 지원 & & & O \\
\hline & 비구속성원조 비율 & & O & \\
\hline \multirow{8}{*}{$\begin{array}{l}\text { 협력대상국 } \\
\text { 제도 발전 } \\
\text { (Fostering } \\
\text { Institutions) }\end{array}$} & 협력대상국의 개발 우선순위에 대한 원조 & O & & \\
\hline & 원조실시기구 이용의 방지 & O & & \\
\hline & 협력대상국 예산에 활용된 원조 & & O & \\
\hline & 좋은 운영전략을 이용한 원조 & O & & \\
\hline & 협력대상국의 시스템 사용 & O & & \\
\hline & 기술협력의 조화 & O & & \\
\hline & 계획된 원조가 실제 공여된 정도 & & O & \\
\hline & 미래의 예산 계획의 보급 & & O & \\
\hline \multirow{7}{*}{$\begin{array}{c}\text { 협력대상국 } \\
\text { 행정부담 감소 } \\
\text { (Reducing the } \\
\text { Administrative } \\
\text { Burden) }\end{array}$} & 원조 관계의 중요도 & O & & \\
\hline & 원조기구의 분산화 & O & & \\
\hline & 중간 프로젝트 규모 & O & & \\
\hline & 다자기구 지원 & & O & \\
\hline & 공동 미션 & 0 & & \\
\hline & 공동 연구 실시 & 0 & & \\
\hline & 프로그램형 원조의 활용 & O & & \\
\hline \multirow{8}{*}{$\begin{array}{c}\text { 원조 투명성 } \\
\text { (Transparency } \\
\text { and learning) }\end{array}$} & IATI (International Aid Transparency Initiative) 가입 & & & O \\
\hline & 프로젝트 제목과 내용 기록제출 & & O & \\
\hline & 프로젝트의 세부내용 제공 & & O & \\
\hline & 원조 제공 방식에 대한 정보제공 & & O & \\
\hline & 원조 지급액에 대한 정보 제공 & & O & \\
\hline & 프로젝트 정보 제공 & & O & \\
\hline & 주요공여기관 평가정책의 질 & & O & \\
\hline & 좋은 모니터링, 평가 체제 & O & & \\
\hline
\end{tabular}

※ 출처 : 저자 재구성 / 참고문헌 : KOICA 개발정책 포커스 2012년 11호 p17 


\section{(1) 효율성 최대화(Maximizing Efficiency)}

효율성 최대화 세부항목의 경우, '빈곤국에 대한 원조 할당' '낮은 행정비용,' ‘비구속성원

조 비율,' ‘국제공익시설에 대한 지원' 분야를 제외하고는 적정기술 도입에 따른 긍정적 효과가 직접적이고 매우 클 것으로 보인다. 그동안 한국은 경제, 사회적으로 교류나 연관성이 높은 아 시아의 중소득국가에 많은 양의 원조를 할애하여 원조의 효율성 최대화항목에서 낮은 평가를 받았다. 이러한 부분이 적정기술을 활용한다고 해서 크게 효과가 있을 것으로 보이지는 않는다. 다만 적정기술을 통해서 전문성이 있는 현지화 전략들이 만들어진다면 그 전문성을 통해서 다 른 지역으로 확대화하는 새로운 전략들이 만들어지면서 기존의 관계 중심적이면서 요청주의에 의존하는 사업 개발 방식에 벗어나는 효과를 기대할 수 있다는 측면에서 '빈곤국에 대한 원조 할당' 에 대한 보통의 효과정도는 기대할 수 있을 것으로 보았다. 또한 적정기술이 파트너 국가 들의 역량강화라는 요소까지 만들어내기 위해서는 지역의 거버넌스 구조에 민감할 수밖에 없게 된다. 따라서 거버넌스 구조를 기반으로 지역 주민들의 역량 강화에 대한 각각의 프로젝트를 설 계함으로서 이들 요소에 높은 효과가 있을 것으로 보았다. 또한 이러한 요소는 앞서 설명한 바 와 같이 프로그램 기반의 사업을 지향하게 되므로 CPA (Country Programmable Aid)비율을 높이는데 기여하게 된다.

'비교 우위가 있는 국가에 지원(Focus/specialization by recipient country)' 항목의 경우, 우리나라는 유, 무상원조의 중점지원국과 일반지원국으로 구분되어 있으므로 중점지원국을 중 심으로 현지 데이터를 수집하고 그에 필요한 지원을 적정기술을 활용하여 대응할 때 비교우위 를 나타낼 수 있다. 특히 그동안 한국이 주로 공여했던 아시아지역에 대한 기존 경험을 활용할 경우 아시아 지역에 대한 비교우위를 나타낼 수 있다. 또한 한국이 적정기술을 기반으로 한 $\mathrm{ODA}$ 전략을 수립할 경우, 한국은 특허강국으로 많은 지적재산권과 기술력을 보유하고 있으며, 현지인에게 적정기술을 보급하고 기술을 전수할 수 있는 인력자원이 충분하기 때문에 적정기술 을 활용하여 비교우위 영역을 넓혀갈 수 있다. 기존의 우리나라가 비교우위를 보인 교육, 보건 의료, 정보통신 분야 등에 적정기술을 활용할 경우 한국만의 특화된 지원 방식을 활성화할 수 있어 더 많은 예산을 할애할 수 있을 것으로 보인다. 따라서 '비교 우위가 있는 분야에 지원 (Focus/specialization by sector)' 영역의 평가지표를 향상시키는 결과를 가져 올 수 있다.

낮은 행정 비용과 비구속성원조 비율에 대한 적정기술의 긍정적인 영향은 중장기적으로 나타 날 것으로 보인다. 낮은 행정 비용의 경우, 적정기술 초기단계에는 다양한 전문가의 참여와 국 내와 현지사무소의 개입이 필요하지만 장기적으로 볼 때, 개도국의 역량이 강화되면 공여국의 개입이 줄고 개도국의 역할이 커지게 되어 행정비용을 낮출 수 있다. 


\section{(2) 협력대상국 제도 발전(Fostering Institutions)}

적정기술의 활용은 협력대상국과의 파트너십을 통하여 궁극적으로 협력대상국의 역량을 개발 하는데 목적을 두고 있으므로 '협력대상국 제도 발전' 항목 순위 상승에도 크게 기여할 것으로 기대된다. 우선, 적정기술을 활용한 $\mathrm{ODA}$ 는 현재 활용 가능한 적정기술을 데이터베이스화 하면 다양한 사업분야에 걸쳐 활용이 가능하다는 장점이 있다. 따라서 각 협력대상국의 현지 상황과 개발전략에 대한 정보를 바탕으로 이에 적합한 적정기술을 원조사업에 도입하여 협력대상국의 개발 의지에 힘을 실어 줄 수 있다. 또한 적정기술은 협력대상국과 파트너십을 통하여 현지 사 정과 지역 주민의 역량에 맞는 적정기술 보급을 통한 삶의 질 개선이 목적이므로 협력대상국과 의 협력 및 시스템 활용도가 높아질 것으로 예상되며, 이에 따라 '기술협력의 조화' 나 '좋은 운 영전략을 이용한 원조' 항목도 같이 상승될 것으로 기대된다.

아울러 '계획된 원조가 실제 공여된 정도' 와 '미래의 예산 계획의 보급' 항목은 원조의 예측 가능성을 높여 협력대상국에 이에 맞는 국가 예산 계획을 세울 수 있는 장점이 있다. 적정기술 을 활용한 $\mathrm{ODA}$ 가 프로그램화되면 현재의 단년도 예산에서 중장기화된 예산으로 진행할 수 있 으므로 이에 대한 평가가 향상될 것으로 기대된다.

\section{(3) 협력대상국 행정부담 감소(Reducing the Administrative Burden)}

매년 8만 개 이상의 원조 프로젝트가 협력대상국 정부에게 주는 행정적 비용 부담은 엄청나 다. OECD가 추산한 바에 따르면, 매년 원조 협력대상국이 수행하는 평균 263개의 미션과 관련 된 손실은 50 억 달러에 달한다. ${ }^{22)}$ '원조 관계의 중요도' 항목에서는 한 나라에 공여하는 국가 수가 많을수록 협력대상국의 행정적 부담은 증가되므로 특정 협력대상국에 얼마만큼의 원조 기 여도가 있는지 평가한다. 우리가 지향하는 적정기술을 활용한 $\mathrm{ODA}$ 는 프로그램형 사업이므로 '프로그램형 원조의 활용' 이 늘어나게 되고, 특정 협력대상국에 대한 원조 기여도가 기존의 프 로젝트형 사업을 할 때 보다 향상될 것이다. 또한 적정기술을 활용하여 과학기술 분야라는 핵심 적 영역을 중심으로 원조를 실시할 경우 '원조기구의 분산화' 에 대한 평가가 상승될 것으로 기 대한다.

‘중간 프로젝트 규모' 역시 적정기술을 주류화한 프로그램형 원조가 실시되면 현재의 소규모 단위의 프로젝트 사업 보다 장기적이고 큰 규모의 사업이 진행될 것으로 보이므로 이 항목의 상 승이 예상된다. 또한 적정기술이 가지고 있는 다양한 융합적 요소들은 자연스럽게 사업진행을 위해서 국내외 $\mathrm{NGO}$, 국제기구 그리고 타 공여국간의 파트너십 구축을 지향하게 될 것으로 예 측된다. 이로 인해 공동 사업을 발굴하거나 공동연구가 가능할 것으로 기대된다.

22) Nancy Birdsall외 「Quality of Official Development Assistance Assessment」, p.33 


\section{(4) 원조 투명성(Transparency and learning)}

원조의 투명성에 대한 각 항목은 프로젝트에 대한 정보를 공개하는 IATI에 가입여부 혹은 원 조에 대한 정보를 $\mathrm{OECD}-\mathrm{DAC}$ 에 제출하는지에 대한 항목 등이 이에 해당된다. 장기적으로 적 정기술을 활용한 ODA가 지속적으로 발전하려면 협력대상국 현지 수요와 이에 대응할 수 있는 적정기술을 매칭할 수 있는 데이터베이스 구축이 중요하다. 따라서 현재 진행되고 있는 원조에 대한 정보 또는 모니터링과 평가 결과를 공개하고 데이터베이스화하여야 하여 원조 투명성에 대한 평가항목들의 상승과 함께 원조의 효과성을 높일 수 있을 것으로 기대한다.

\section{나. 적정기술 도입을 통해 개발효과성을 높이기 위한 정책적 과제}

부산 글로벌 모니터링 지표와 공적개발원조 질적평가 $(\mathrm{QuODA})$ 지표에 따른 한국원조의 질적 인 성장을 위해서는 무엇보다 원조정책과 집행체제의 전반적인 변화가 필요하다. 특히 기존 프 로젝트 중심의 원조 관행 하에서는 향후 진행되는 국제적 원조평가에 있어서 결코 좋은 결과를 만들어 낼 수 없다. 이를 해결하기 위해서는 프로그램 기반 접근(Program-Based Approaches; PBA)의 점진적 도입 등 한국 원조 집행체제에 대한 보다 체계적이고 종합적인 정책 검토가 병행되어야 할 것이다. ${ }^{23)}$

국제사회는 기존의 전통적인 프로젝트 방식의 원조에서 벗어나고자 2005년 파리선언을 비롯 해서 지속적인 원조효과성 회의를 통해서 국제개발원조의 파트너십 강화, 성과 극대화 측면에 서 협력대상국의 주인의식과 원조공여자간의 조화를 더욱 강조하는데 합의하였다. 특히 파리선 언의 '원조효과 제고를 위한 12 개의 발전 지표(12 Indicators of Progress)' 는 전통적인 방식 이 아닌 프로그램 접근방식의 새로운 원조 실시 기법을 도입하는 것에 대한 목표를 제시한 바 있다. ${ }^{24)}$ 또한 부산 글로벌 모니터링 지표에서도 구체적인 항목으로 되어있지는 않지만 전반적 으로 내용들 속에 녹여져 있다.

세계 각국의 원조기관들은 이러한 변화에 맞추어 프로그램 방식의 원조 사업으로의 변화를 진 행하고 있다. 캐나다의 경우는 2002년부터 새로운 프로그램 접근 방식을 도입하여 전체 사업의 $1 / 3$ 이상을 이 방식에 입각하여 시행하고 있다. 일본 JICA의 경우 2006 년 23 개 주요 분야 과 제 부분에서 39 개의 사업을 프로그램접근 방식으로 추진해 나가고 있다. 또한 덴마크는 2008 년 6월, 섹터별 프로그램 지원(Sector Programme Support; 이하 SPS)을 자국의 핵심 원조 방식으로 정리하고 기존 사업을 SPS의 틀 내에서 통합하는 체제를 구축하고 있다. ${ }^{25)}$ 이러한 추

23) 홍상희 「부산 글로벌 파트너십 출범과 우리나라 ODA 정책과제」KOICA 국제개발협력 2012년 3호 p18 참조

24) KOICA, 「한국적 개발협력 프로그램 발전방안 연구_2007. p2 참조 
세 속에서 한국의 원조정책도 프로그램접근 방식의 도입을 위한 체계구축을 중장기 과제로 진 행하고 있다.

\section{5. 결론}

한국은 짧은 원조의 역사 속에서 최근 급격한 변화를 맞이하고 있다. 2009년 OECD-DAC 에 가입한 이후 2 년 후 원조와 관련해서 가장 큰 세계개발원조총회를 2011년 부산에서 개최했 다. 아직은 국제적 평가 기준에 맞춰져 있지 못한 것이 많아서 여전히 국제적 평가에 있어서는 결과가 좋지 못하다. 그럼에도 불구하고 원조와 관련해서 국내외적 요청에 맞추기 위해서 노력 을 거듭한 결과 앞서 살펴본 2가지 평가에 있어서 발전을 거듭하고 있는 것을 확인할 수 있다. 그러나 여전히 국제적인 평가기준들은 한국의 원조에 있어서 많은 도전과제를 안겨주고 있다.

앞서 이야기한 바와 같이 적정기술의 적용이라는 측면이 매우 다양한 상황 속에서 그 예상 효과를 짐작하는 것은 큰 오류를 범하기 쉽다. 그럼에도 불구하고 이 글은 앞으로의 상황을 가 정해서 국제적인 원조평가기준들 속에서 적정기술의 효과성을 설명하고 있다. 이는 적정기술의 근본 철학인 현장에 적합한 방식으로 인간에게 도구화되어지는 가치가 우리가 추구해야하는 원 조의 방향과 일치한다는 생각이 있기 때문이다. 그러나 앞서 살펴본 바와 같이 적정기술이 본격 적으로 도입되어 우리나라의 원조에서 적극적으로 활용되기 위해서는 넘어야할 과제가 여전히 많다. 그러나 그 과제의 높은 벽에 좌절하기 보다는 함께 노력하면 넘을 수 있다는 확신을 가지 고 한 걸을 한 걸음 노력하는 자리들이 지속적으로 만들어지길 기대해 본다.

25) KOICA, 「한국 ODA의 프로그램형 접근법(PBA) 도입방안, 2010. p17 


\section{참고문헌}

\section{1. 국내문헌}

김형규, 「파리선언 이행평가 최종보고서 발표」주OECD대표부(http://oecd.mofat.go.kr) 2011 국제개발협력시민사회포럼(KoFID)「이슈 브리프 8호」글로벌발전연구원(ReD), 2011

박수영, 조아영, 「원조효과성을 위한 파리선언 이행체제평가연구 보고서」KOICA, 2009 한재광 외 6, 「파리선언을 넘어서」ODA Watch 2012.

홍상희 「부산 글로벌 파트너십 출범과 우리나라 ODA 정책과제」KOICA 국제개발협력 2012년 3호 홍성욱, 「개도국을 위한 적정기술 개발 지원 방안 연구」서울대학교 과학문화연구센터, 2012.

$\mathrm{KOICA}$, 「한국 ODA의 프로그램형 접근법(PBA) 도입방안」, 2010.

$\mathrm{KOICA}$, 「한국적 개발협력 프로그램 발전방안 연구」2007.

\section{2. 국외문헌}

Bakker, 「The Gandhian Approach to Swadeshi or Appropriate Technology: A Conceptualization in Terms of Basic Needs and Equity」, Journal of Agricultural and Environmental Ethics, 1990

Geoge Mcrobie, 「Small is Possible」HarperCollins Publishers, 1981

Nancy Birdsall외, 「Quality of Official Development Assistance Assessment」,2010, OECD-DAC, 「Special Review of Korea」, OECD-DAC, 2008, Pursell, 「 American Technology」, Wiley-Blackwell, 2001

Winner, 「The Whale and the Reactor. 1st ed」, University of Chicago Press, 1986 